\title{
Osteoderm microstructure of Riostegotherium yanei, the oldest Xenarthra
}

\author{
LÍLIAN P. BERGQVIST ${ }^{1}$, PAULO VICTOR LUIZ G.C. PEREIRA ${ }^{2}$, ALESSANDRA S. \\ MACHADO ${ }^{3}$, MARIELA C. DE CASTRO ${ }^{4}$, LUIZA B. MELKI ${ }^{2}$ and RICARDO T. LOPES ${ }^{3}$ \\ ${ }^{1}$ Departamento de Geologia, Universidade Federal do Rio de Janeiro, Av. Athos da Silveira Ramos \\ 274, Bl. G, Sala G1053, Ilha do Fundão, 21941-611 Rio de Janeiro, RJ, Brazil \\ ${ }^{2}$ Programa de Pós-graduação em Geologia, Universidade Federal do Rio de Janeiro, Av. Athos da \\ Silveira Ramos 274, B1. G, sala G1053, Ilha do Fundão, 21941-611 Rio de Janeiro, RJ, Brazil \\ ${ }^{3}$ Laboratório de Instrumentação Nuclear, Universidade Federal do Rio de Janeiro. Centro de \\ Tecnologia, Bloco I, Sala I-133, Ilha do Fundão, 21941-972 Rio de Janeiro, RJ, Brazil \\ ${ }^{4}$ Departamento de Ciências Biológicas, IBiotec, Universidade Federal de Goiás, Regional Catalão, Av. \\ Castelo Branco, s/n, St. Universitário Campus II, Sala 6, 75704-020 Catalão, GO, Brazil
}

Manuscript received on December 3, 2018; accepted for publication on May 3, 2019

\begin{abstract}
How to cite: BERGQVIST LP, PEREIRA PVLGC, MACHADO AS, CASTRO MC, MELKI LB AND LOPES RT. 2019. Osteoderm microstructure of Riostegotherium yanei, the oldest Xenarthra. An Acad Bras Cienc 91: e20181290. DOI 10.1590/0001-3765201920181290.

Abstract: Riostegotherium yanei from the Itaboraí Basin, Brazil, is the oldest known Xenarthra. This paper aims to describe the internal morphology of the osteoderms of Riostegotherium yanei from the perspective of histology and micro-CT approaches, expanding the available data on cingulate osteoderm microstructure. Seven osteoderms of $R$. yanei were used for the internal microstructure description and eight of Dasypus novemcinctus for comparison. The osteoderms of Riostegotherium yanei lacks the diploë-like structure typical of glyptodonts but has a three-layered structure composed of two layers of non-Haversian compact bone enclosing a central layer of primary and secondary osteons. This internal organization is distinct from other Astegotheriini of comparable age, but similar to Dasypus. The 3D reconstruction of Riostegotherium yanei revealed two patterns of internal organization. Pattern 1 of movable osteoderm is composed of large remodeled areas at the base and a more compact bone at the tongue; in Pattern 2 (both movable and buckler), the internal cavities are much smaller, more numerous, and more interconnected to each other. In one buckler osteoderm, the cavities are organized somewhat radially with a compact central region (Pattern 1). Pattern 1 of both movable and buckler osteoderms resemble that of Dasypus.
\end{abstract}

Key words: Itaboraí basin, Paleogene, Dasypodidae, histology, 3D.

\section{INTRODUCTION}

Armadillos comprise a restricted group of 21 extant species of xenarthrans (Wetzel 1985a, Wetzel

Correspondence to: Lílian Paglarelli Bergqvist

E-mail: bergqvist@geologia.ufrj.br

ORCid: https://orcid.org/0000-0002-8090-8849

* Contribution to the centenary of the Brazilian Academy of Sciences. 1985b, Vizcaíno 1995) distributed exclusively throughout the Neotropical region, except for Dasypus novemcinctus (Linnaeus, 1758) that dispersed to North America (Aguiar and Fonseca 2008, Woodburne 2010). Within Xenarthra, armadillos and its relatives (pampatheres and glyptodonts) compose a monophyletic group called Cingulata (Engelmann 1985, Gaudin and 
Wible 2006, Gibb et al. 2015, McDonald 2018), which possess osteoderms (also known as scutes or ossicles). Osteoderms are dermal ossification within the integument, overlaid by epidermal cornified scales, forming a complex exoskeleton, and are a remarkable feature that occurs in no other mammals. These ossifications are found, as well, in Mylodontidae, an extinct family of ground sloths, making some authors believe that the presence of osteoderms is an ancestral feature of Xenarthra (Engelmann 1985, Rose and Emry 1993, Hill 2006). Different from mylodontids, where joint surfaces or sutures are absent, the osteoderms of cingulates are closely articulated with one another, covering the head dorsally, the trunk dorsally and laterally, and encasing the tail. Additionally, osteoderms may be scattered within the integument of the rostrum, ventral surface of the trunk, and on the limbs (Krmpotic et al. 2009). Concordantly, isolated osteoderms are the most frequent elements in the fossil record of Cingulata, being found in almost every South American mammal fauna known since Itaboraian age (Carlini et al. 2009).

Riostegotherium yanei Oliveira and Bergqvist, 1998 is the oldest Xenarthra yet discovered and is known only by isolated osteoderms. It was recovered from the Itaboraí Basin, of Paleocene/ Eocene age. Its presence in the basin suggests that Xenarthra differentiated somewhere in the South American continent (Pascual and Ortiz-Jaureguizar 2007). This view, based on fossil records, received support from recent molecular studies, which estimated the divergence time of Xenarthra by the Cretaceous-Paleogene boundary (Meredith et al. 2011, Delsuc et al. 2012, Gibb et al. 2015).

Studies about xenarthran osteoderm microstructure and its applications have increased in recent years, mainly in phylogenetic relationships and reconstruction of soft tissues in fossil osteoderms (e.g. Hill 2006, Wolf 2007, Wolf et al. 2012, Chávez-Aponte et al. 2008, Krmpotic et al. 2009, 2015, Ciancio et al. 2017). For about
10 years, all data came from histological thin sections, but the last two publications employed also, for the first time, $\mathrm{x}$-ray microtomography and $3 \mathrm{D}$ reconstructions of the internal microstructure.

The main purpose of this study is to provide a detailed description of the microstructure of movable and buckler osteoderms of Riostegotherium yanei from the perspective of histology and microCT approaches, expanding the available data on cingulate osteoderm microstructure. Considering that the species represents the oldest Xenarthra known so far, its morphology may be a proxy of the ancestral condition of the clade.

\section{PREVIOUS STUDIES OF ITABORAÍ XENARTHRANS}

Paula-Couto (1949) was the first to mention of the presence of xenarthrans in the Itaboraí Basin. However, the specimens (two osteoderms) were only studied about thirty years later by ScillatoYané (1976), who assigned this material to Prostegotherium aff. P. astrifer, an early Eocene (Casamayoran SALMA) cingulate from Argentina. Based on new isolated osteoderms, Oliveira and Bergqvist (1998) concluded that the specimens from Itaboraí were distinct from $P$. astrifer Ameghino, 1902, as well as from any Paleogene Patagonian cingulate and coined the new taxon Riostegotherium yanei. More recently, Bergqvist et al. (2004) redescribed these osteoderms, providing a revised diagnosis for the species. They also described a couple of postcranial bones, including two humeri of distinct size and morphology, corroborating the presence of at least two cingulate species in the Itaboraí Basin, as previously suggested by Cifelli (1983); however, the larger astragalus and humerus are more dasypodoid-like than the others. The osteoderms recovered in the basin vary little with a similar external morphology. The differences among them are subtle and can be regarded as individual variation and/or position in the carapace. Therefore, they were all assigned 
to Riostegotherium yanei (Bergqvist and Oliveira 1998, Bergqvist et al. 2004). The postcranial bones, however, could only be assigned to the tribe.

GEOLOGY AND AGE OF THE ITABORAÍ BASIN

The fissure-fill deposits cut the freshwater travertine that fills the Itaboraí Basin, in the state of Rio de Janeiro, southeastern Brazil (2250'20'S, $\left.42^{\circ} 52^{\prime} 30^{\prime \prime} \mathrm{W}\right)$. This small basin has a rhomboedric shape with the largest axis NE-SW (1,400 m long), the smaller axis NW-SE direction (500 m long), and a maximum depth of about $125 \mathrm{~m}$, which was observed near the São José Fault at its southern limit. The Itaboraí Basin is now part of the Natural Park of São José de Itaboraí and the depression left with the limestone extraction is now flooded.

Oliveira (1956) called the Itaboraí Formation the package of limestone layers which fill up the Itaboraí Basin. However, such lithostratigraphic name, with few exceptions, was not used by the following authors, who preferred to call the deposit just the Itaboraí Basin.

Since Marshall (1985), the Itaboraí Basin has been referred to the Itaboraian SALMA (58.3$57 \mathrm{Ma}$, Bond et al. 1995). Recent analyses of Paleogene mammalian assemblages and mammalbearing deposits in Argentina, together with new radioisotopic dating (Gelfo et al. 2009, Woodburne et al. 2014), suggested that the Itaboraian SALMA in Argentina is somewhat younger than previously believed, probably ranging from 53-50 Ma (early Eocene). Study in progress by the senior author challenges this latter interpretation, suggesting that at least part of the fissures was formed and filled during the late Paleocene.

\section{MATERIALS AND METHODS}

Seven osteoderms of Riostegotheirum yanei (LMH 05 [movable], LMH 06 [movable], UFRJ-DG 317M [movable], MCT 3932-M [buckler], MCNPV 1775 [buckler], MCN-PV 1777 [movable], and MCN-PV 1779 [movable]) were used for microstructure description. Paula-Couto (1949) mentioned the recovery of cingulate osteoderms from the fissure discovered and worked in 1948 (all specimens collected in this fissure were deposited at Museu Nacional [MN] fossil collection, in Rio de Janeiro, Brazil). However, no cingulate is registered in this collection. The specimens studied belong to Museu de Ciências da Terra (MCT) fossil mammal collection, Universidade Federal do Rio de Janeiro - Departamento de Geologia (UFRJ-DG) fossil mammal collection, both in Rio de Janeiro, and Museu de Ciências Naturais of Fundação Zoobotânica, paleovertebrate collection (MCNPV), in Porto Alegre, Brazil. No information about the provenance of the specimens in the Itaboraí basin is available.

Due to the paucity of the $R$. yanei specimens in the Itaboraí basin, only two uncatalogued osteoderms from movable bands were available for histological section. They received provisional laboratory numbers LMH 05 and LMH 06. Seven thin sections (three of LMH 05 and four of LMH 06) were prepared and the remaining embedded material and slices are housed at Laboratório de Macrofósseis of Universidade Federal do Rio de Janeiro (UFRJ). The slices described and/or cited here are deposited at the Fossil Mammal Collection of Departamento de Geologia at UFRJ, under the numbers UFRJ-DG 1049M, 1050M, 1051M, (specimen LMH 05, slices a, b, and c, respectively) and UFRJ-DG 1052M, 1053M (specimen LMH 06 , slices a and $\mathrm{b}$, respectively).

LMH 05 and LMH 06, as well as the osteoderms UFRJ-DG 317M (movable), MCT 3932-M (buckler), MCN-PV 1775 (buckler), MCNPV 1777 (movable), and MCN-PV 1779 (movable) were CT scanned. LMH 05 was scanned after being sectioned (the two remaining lateral parts of it).

For comparison with $R$. yanei, eight isolated osteoderms of the extant nine-banded armadillo Dasypus novemcinctus, donated to Laboratório 
de Macrofósseis - LMH 83.1 (buckler), LMH 83.2 (movable), LMH 98.1 (buckler), LMH 98.2 (movable), LMH 98.3 (movable), LMH 98.4 (buckler), LMH 98.5 (buckler), LMH 98.6 (movable) were also scanned.

\section{HISTOLOGY}

The osteoderms LMH 05 and LMH 06 were sectioned along their longest axes after being embedded in epoxy resin. LMH 06 was also transversely sectioned. The specimen LMH 05 was cut with a Linear Precision Saw Buehler Isomet 4000 and LMH 06 with a Precision Thin Section Cutting and Grinding Metkon Geoform. The slices of both specimens were later polished in an Arotec polisher with $54 \mu$ and $18 \mu$ polishing diamond discs, and then affixed on a frosted glass slide. The sections were thinned to $30 \mu \mathrm{m}$ initially, with the diamond grinding wheel from Geoform, then polished with $18 \mu$ diamond disc and finished with silicon carbide 2500 .

All slices were observed and digitally photographed under both plane and cross-polarized light, with and without a compensator, using a Carl Zeiss Imager.A2m petrographic microscope, under the magnifications of $1.25 \times, 2.5 \times, 5 \times, 10 \times$, and $20 \times$.

The terminology employed for osteoderm description followed Wolf et al. (2012).

\section{X-RAY MICROTOMOGRAPHY (MICRO-CT)}

Micro-CT physical principle is based on the attenuation of X-rays when they interact with the object. The intensity of the photons crossing the object depends on the number of atoms by volume unit (density). Essentially, the quality of a microCT image depends on spatial resolution, contrast, and signal ratio noise. One of the most important parameters in micro-CT is the scanning pixel size, which is linked to spatial resolution of the system (Stock 2008, Oliveira et al. 2011).
Micro-CT images of the above-mentioned specimens were obtained in a high-energy microtomography system - Skyscan/Bruker, model 1173, with an interslice distance between 6 and 7 $\mu \mathrm{m}$ and resolution about $15 \mu \mathrm{m}$ (for details and other parameters see Supplementary Material Table SI). Samples were placed in a polystyrene support. An aluminum filter ( $0.10 \mathrm{~mm}$ thick) was used to reduce the contribution of low energy photons (beam hardening effect). A flat panel detector $(2240 \times 2240)$ registered the cone X-ray beam transmission. The projection images were taken over $360^{\circ}$ at each step of $0.5^{\circ}$ rotation. To optimize the process of acquisition, parameters were chosen according to the sample size and goal of the analysis.

The micro-CT images and reconstruction were performed with an appropriate algorithm based on filtered back-projection (Feldkamp et al. 1984). The images were reconstructed using the NRecon $\AA$ software, version 1.6.9.4, to create cross-sectional slices of the specimens. The reconstruction parameters of each specimen are provided in the supplementary material.

To observe the internal microstructure and 3D volumetric reconstruction of the osteoderms, we used three different software: CT vox ${ }^{\circledR}$ (version 2.5.0), Dataviewer ${ }^{\circledR}$ (version 1.4.4), and Avizo $\AA$ Fire (version 7). The key information provided by the micro-CT analyses is essentially related to the size, distribution, and orientation of the internal cavities (pilosal, glandular, adiposal, neurovascular, and Havers and Volkmann channels), as well as secondary remodeling areas of the osteoderm (Cooper et al. 2003, Krmpotic et al. 2015). The cavities were gray scale filtering and rendered after segmentation of the osteoderms by density, with CTAn. More information and data regarding the 3D analysis are provided in the supplementary material. 


\section{BONE ARCHITECTURE MEASUREMENTS}

A micro-CT is well-suited to measure cortical porosity (Cooper et al. 2003, but see Cooper et al. 2007 for the impact of voxel size in this type of analysis). To estimate and compare the volume of open spaces (internal cavities) inside the osteoderms, we employed several parameters proposed by Borah et al. (2001) to measure different aspects of the architecture of trabecular bone. These parameters were applied to evaluate the cortical porosity in the current study using the general approach employed by Cooper et al. (2003).

The following parameters were selected as the most informative to analyze and compare the canal network of the specimens: $\mathbf{B S} / \mathbf{B V}=$ solid surface to volume ratio measured in $3 \mathrm{D}$ within the VOI $\left(\mathrm{mm}^{2} /\right.$ $\mathrm{mm}^{3}$ ) - surface to volume ratio, or "specific surface", is a useful basic parameter for characterizing the thickness and complexity of structures, and was employed to estimate the amount of "solid" bone on the surface and within the osteoderm; $\mathbf{B V}=$ total volume of binarized objects within the VOI $\left(\mathrm{mm}^{3}\right)$; Ca.ConnD = connectivity density - the number of canal intersection per unit volume; $\mathbf{C a} . \mathbf{V}=$ canal volume within the VOI $\left(\mathrm{mm}^{3}\right) ; \mathbf{C a} . \mathbf{V} / \mathbf{T V}=$ cortical porosity $(\%)$ - the relative volume of porous canal; DA = degree of anisotropy - measure of preference in orientation; $\mathbf{T V}=$ tissue volume of the VOI. The volume of interest (VOI $-\mathrm{mm}^{3}$ ) of the 3D images was either the total volume of the osteoderm or volume of 500 slices. This VOI, comprising a smaller, but equal number of slices, to compare the porosity of a specific area of the base, where porosity is most distinct between specimens. The number of slices was defined based on the size of the preserved portion of the base in the smaller specimen (UFRJ-DG 317M). The 500 slices were selected to encompass an area of the base with the major density of cavities. The region of interest (ROI) comprised a rectangular area of $1.12 \mathrm{~mm}^{2}(2.8 \mathrm{~mm} \times 0.4 \mathrm{~mm})$, corresponding to a VOI of $3.63 \mathrm{~mm}^{3}$ in 500 slices, in each osteoderm. In the case of buckler osteoderms, the VOI was selected at the anterior third. These parameters were calculated using CT Analyzer 1.16.4.1 software (SkyScan Bruker).

\section{REPOSITORIES AND INSTITUTIONAL} ABBREVIATIONS

DG-URFJ, Department of Geology of Universidade Federal do Rio de Janeiro (UFRJ), Rio de Janeiro, Brazil; LMH, lab number of histological collection of Laboratório de Macrofósseis/UFRJ; MCNPV, Museu de Ciências Naturais, Vertebrate Paleontology Collection, Porto Alegre, Rio Grande do Sul; MCT-M, Museu de Ciências da Terra, Rio de Janeiro, Fossil Mammal Collection.

\section{SYSTEMATIC PALEONTOLOGY}

XENARTHRA Cope, 1889

CINGULATA Illiger, 1811

DASYPODIDAE Gray, 1821

ASTEGOTHERIINI Vizcaíno, 1994

Riostegotherium Oliveira and Bergqvist, 1998

Included species: Riostegotherium yanei Oliveira and Bergqvist, 1998

Figure 1

\section{HOLOTYPE}

MCN-PV 1774, buckler osteoderm, from the Itaboraí Formation, Itaboraí, Rio de Janeiro, Brazil (Oliveira and Bergqvist 1998).

TYPE LOCALITY, UNIT, AND AGE

Itaboraí Basin, Itaboraí, Rio de Janeiro, Brazil; Itaboraí Formation; early Eocene, respectively.

\section{DIAGNOSIS}

Differs from all known Paleogene astegotheriines in having more than 10 pits in the groove around the main figure on buckler osteoderms (25 pits on the holotype, MCN-PV 1774; and 16 pits on MCNPV 1775) (from Bergqvist et al. 2004). 


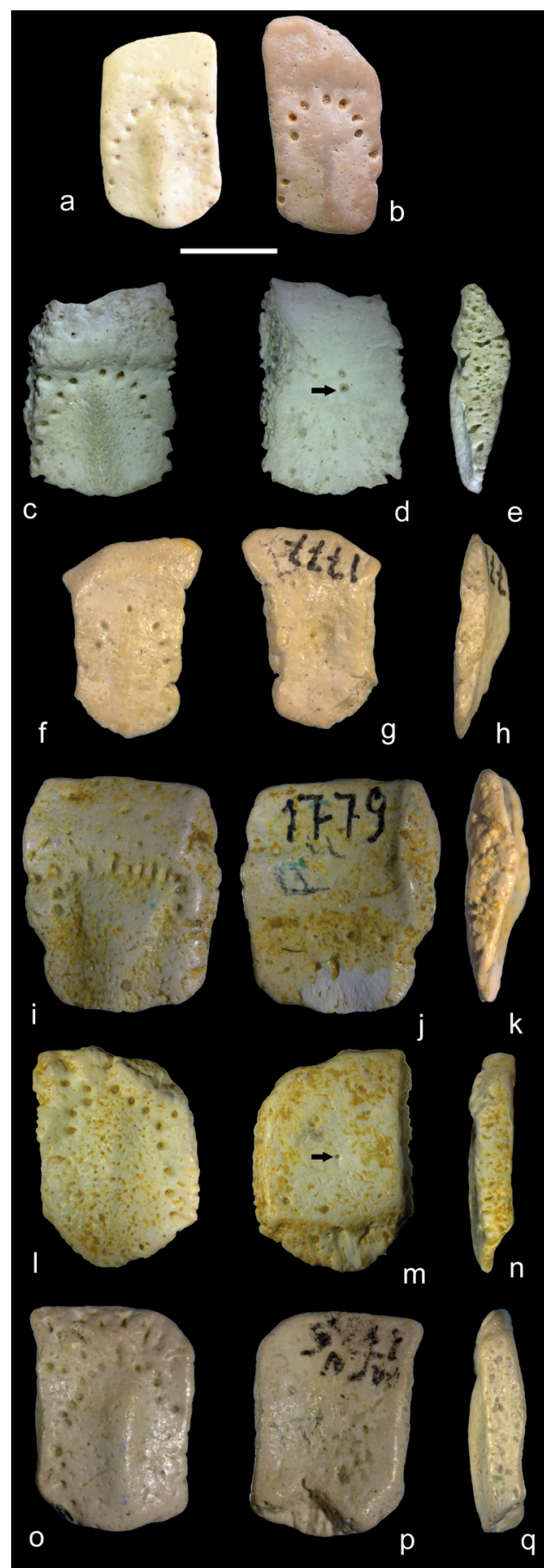

Figure 1 - Movable (a-k) and buckler (l-q) osteoderms of Riostegotherium yanei, a) LMH 05 and b) UFRJ-DG $317 \mathrm{M}$ in external view; c-e, LMH 06; f-g, MCN-PV 1777; i-k, MCN-PV 1779; l-n, MCT 3932-M; o-q, MCN-PV 1775. Scale bar $=5 \mathrm{~mm}$. c, f, i, l, o in external view; $\mathbf{d}, \mathbf{g}, \mathbf{j}, \mathbf{m}, \mathbf{p}$ in internal view; $\mathbf{e}, \mathbf{h}, \mathbf{k}, \mathbf{n}, \mathbf{q}$ in lateral view. Anterior to the top, dorsal to the left. Black arrows indicate foramina of the deep surface.

\section{DESCRIPTION}

All osteoderms from movable bands of $R$. yanei studied here have a rectangular outline, but LMH 06 and MCN-PV 1779 (Figure 1c-e, i-k) are proportionally larger and thicker than the others. Except for LMH 06, the superficial and deep surfaces are smooth and the edges of the osteoderms are rounded, suggesting a longer exposure to abrasion than in the former specimen. None of them are complete; all specimens lack part of the anterior articular surface (= base or anterior non-exposed portion). In MCN-PV 1777, the base is transversely larger than the tongue (= posterior or exposed portion).

The superficial surface of the osteoderms from movable bands is ornamented with small pits scattered all over it, but more abundant over the main figure. It has a moderately developed central keel, which is surrounded anterior and laterally by eight to eleven deep circular depressions (external surface foramina of the glandular cavities, sensu Ciancio et al. 2017), giving a U-shaped outline to the main figure. Different publications have called these deep circular depressions as hair foramina, neurovascular foramina, or simply foramina. A histological section of the extant $D$. novemcinctus (the closest extant relative of Riostegotherium yanei, according to Ciancio et al. 2017) revealed that the cavity beneath each of these deep and large circular depressions at the external surface also contains a complete hair follicle, radically smaller than its external aperture and embedded entirely within the osteoderm (Hill 2006, Krmpotic et al. 2012). Holmes and Simpson (1931) stated that in all pilose armadillos, hair grows from oblique pits in the hinder margin of the osteoderm, through areas of soft skin in between each one. With exception of LMH 06, that may have had only one piliferous foramina at the posterior border, $R$. yanei may have had a smooth carapace, devoid of external thick hair. 
The deep surface is smoothly convex longitudinally and transversely concave at the transition from base to tongue. Its roughness is due to the presence of various small perforations and short meandering sulci. The lateral borders (sutural surfaces) are thicker (mainly in LMH 06 and MCNPV 1779) at the transition from base to tongue, and very rough, suggesting a firm suture between osteoderms from movable bands (Figure 1).

The buckler osteoderms (MCN-PV 1775, MCT 3932-M) are almost complete and have a pentagonal outline, with a straight anterior border (although partially broken in MCT 3932-M; Figure 11-n). As in osteoderms from movable bands, the superficial surface is coarse, covered by small pits, and at least twelve external surface apertures of glandular cavities around the main figure with more near the anterior and lateral borders. The central keel is faintly developed. No peripheral figures are observed. The buckler osteoderms are thicker than the movable ones and all articulating surfaces are rough.

\section{RESULTS}

The internal microstructure of the osteoderms, the main goal of this paper, is presented from the point of view of two distinct perspectives: histological thin sections and 3D reconstructions of micro-CT acquisitions.

\section{INTERNAL MICROSTRUCTURE: HISTOLOGY}

All five longitudinal sections of osteoderms from movable bands of Riostegotherium yanei do not present the diploë-like structure typical of glyptodonts, as defined by Wolf (2007). Although a three-layered structure is observed, like in Dasypus (Hill 2006, Wolf 2007) and Chaetophractus Fitzinger, 1871 (Krmpotic et al. 2009), the core of the osteoderm is not composed of primary or secondary cancellous bone. The two layers of nonHaversian compact bone enclose a central layer of primary and secondary osteons and concentric bony laminae around large cavities (Figure 2), which in recent species host red and yellow marrow, adipose tissue, hair follicles, and apocrine glands (Hill 2006, Krmpotic et al. 2009). No distinct boundaries exist between the superficial and the central layer, as the transition is gradual, but the transition is more abrupt between the core and deep cortex.

The thickness of the superficial and deep cortices is variable along the longer axis of the osteoderm. At the tongue, the deep cortex can be slightly or almost two times thicker than the

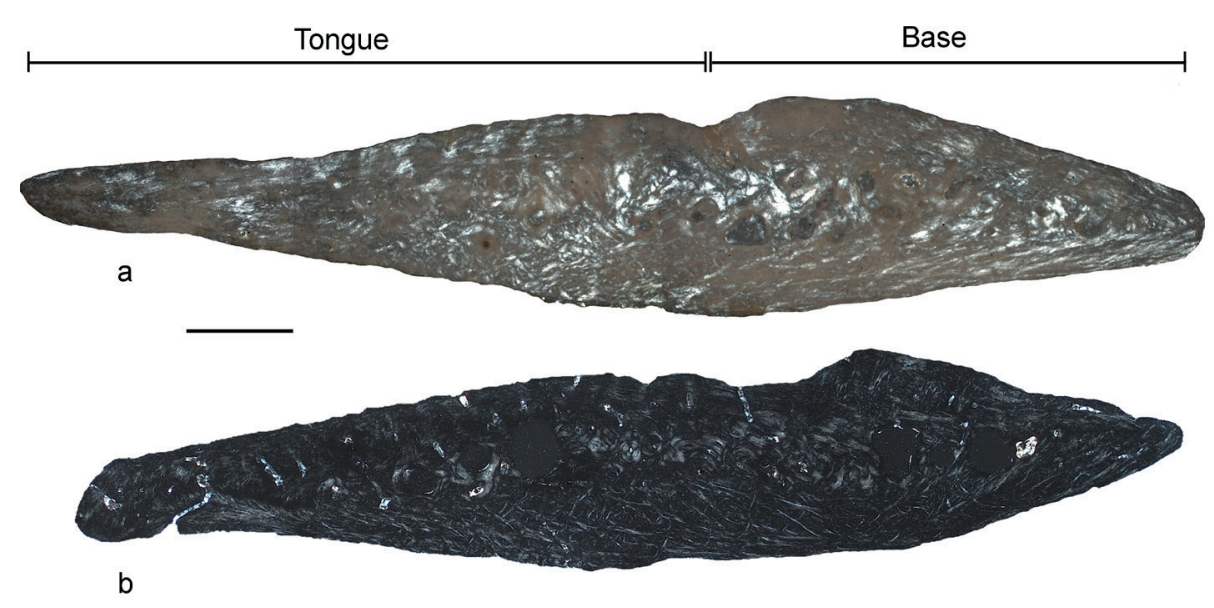

Figure 2 - Longitudinal section of osteoderms from movable bands of Riostegotherium yanei, a) UFRJ-DG $1051 \mathrm{M}$; b) UFRJ-DG $1053 \mathrm{M}$ (horizontally inverted). Scale bar $=1 \mathrm{~mm}$. Anterior to the right. Polarized light. 
superficial cortex (in slices closer to the sagittal plane). At the base, both superficial and deep layers of compact bone are thinner due to the enlargement of the central region. Underneath the external depression at the transition from base to tongue, the deep cortex is thicker than the superficial layer.

The superficial cortex is formed of lamellar bone. It contains mineralized fiber bundles that run predominately parallel to the long axis of the osteoderm. The fibers are thin and long in LMH 06 but thicker in LMH 05; they are regularly arranged, slightly undulating, and run parallel to the osteoderm surface. Several anteroposteriorly elongated, almost evenly spaced, and aligned osteocyte lacunae are arranged in layers parallel to the superficial surface (Figure 3a). Close to the steep edge at the posterior margin of the base, the surface-parallel collagen fibers of the superficial cortex of the base cross the radially oriented bundles, forming an almost orthogonal pattern of fibers (Figure $3 b$ ).

At the posterior edge of the osteoderm, the sections of both LMH 05 and 06 present crossed
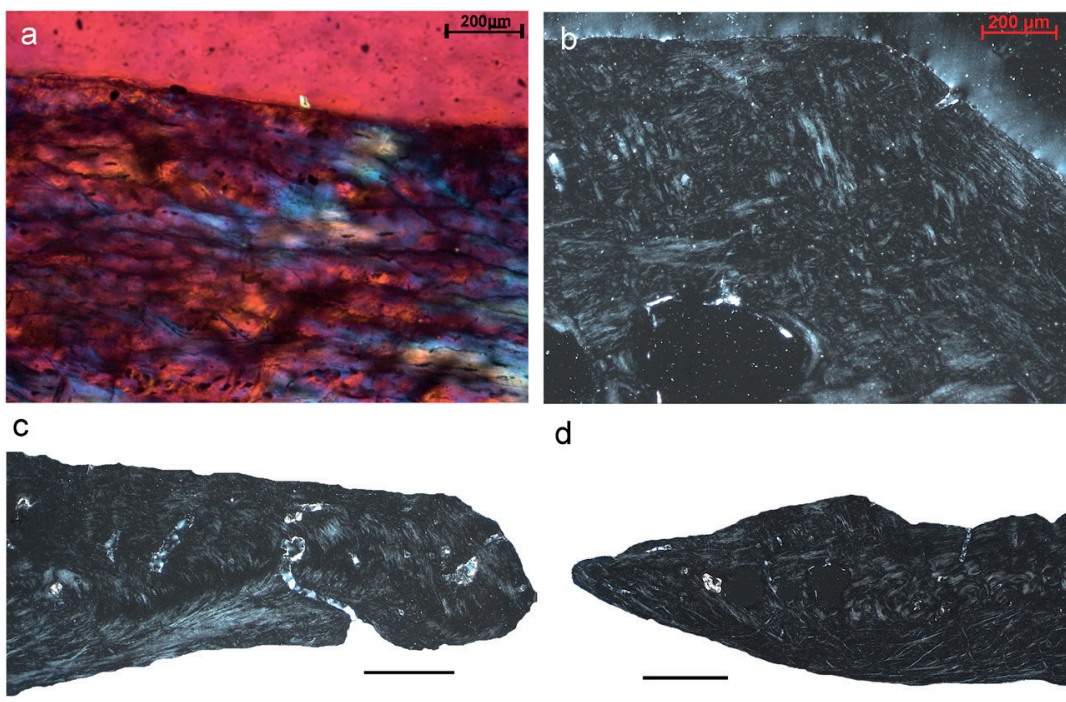

d
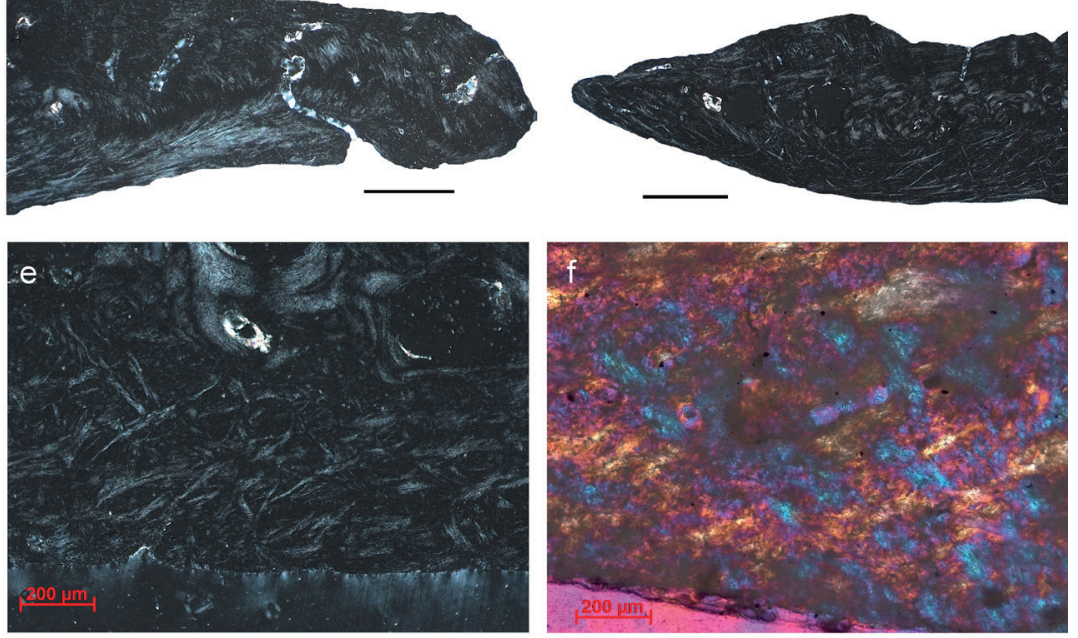

Figure 3 - Histological details of the osteoderms of Riostegotherium yanei, a) aligned osteocyte lacunae at the superficial cortex (UFRJ-DG 1050M); b) the almost orthogonal pattern of collagen fiber bundles at the posterior part of the superficial cortex of the base (UFRJ-DG 1052M); c) layers of different directions near the posterior edge of the tongue give the false impression that the fibers are curved (UFRJ-DG 1053M); d) the thick fibers of the deep cortex are crossed by few fiber bundles oriented anterior and superficially (UFRJ-DG 1053M); e) detail of the irregular meshwork pattern of the deep layer, at the middle region of the osteoderm with polarized light; and $\mathbf{f}) \lambda$ compensator (UFRJ-DG 1052M and UFRJ-DG 1050M, respectively). Scale bar = $200 \mu \mathrm{m}$ in (a), $1 \mathrm{~mm}$ in (c) and $0.5 \mathrm{~mm}$ in (d). 
layers of collagen fibers of distinct directions (see Currey 2006). This different fiber direction of each layer gives the impression that the superficial bundles bend to be continuous with the fibers of the deep region (Figure 3c).

The collagen fibers of the deep cortex are thicker and less organized than in the superficial cortex. At the base, the fiber bundles are longer and run parallel or slightly oblique to the deep surface, crossed by several oblique fiber bundles at angles of at least $45^{\circ}$ (Figure 3b, d). These strengthening adaptations are also observed in Dasypus novemcinctus, representing a reinforcement for providing additional stability in the movable bands, an especially flexible carapace part (Wolf 2007). Towards the middle third of the osteoderm, the bundles grade to a non-preferential fiber orientation, with short and thick fibers extending irregularly in multiple directions, forming an irregular meshwork. In the posterior third, the fibers are thinner (like the superficial ones), shorter and run mostly oblique to the deep surface, some anteriorly directed and some (the deepest) posteriorly (Figure 3e, f).

A few shorter and dense bundles, oriented anterior and superficially, cross in oblique direction the parallel bundles of the posterior portion of the tongue (Figure 3c).

Both deep and superficial cortices are poorly vascularized, especially the specimen LMH 05. Few primary osteons and vascular channels (but no secondary osteons) are present in the superficial cortex, and they are mostly located at the middle portion of the tongue (Figure 4). They are somewhat more frequent in all slices of LMH 06. Most primary osteons are rounded and only a few are elongated.

Vascularization is even more rare within the deep cortex in $R$. yanei. Just one rounded primary osteon is observed in one slice of the specimen LMH 05 , near the central region of the tongue (Figures $3 \mathrm{a}, 5 \mathrm{a})$; a couple vascular canals are present at the tip of the tongue in LMH 06.
The core of both osteoderms is remodeled by numerous secondary osteons, oriented perpendicular to the plane of the section, and few large (larger in LMH 06) resorption areas (some of them surrounded by concentric bone lamellae) at both base and tongue (Figures 3, 5). Secondary osteons are concentrated at the contact between base and tongue and in some extension of the tongue. The size of the Haversian canals is variable, but several are moderate to large. According to Pfeiffer et al. (2006), large Haversian canals and high variability in their size may indicate a metabolically active cortical bone at the time of death. The secondary osteons form a network and between them lay interstitial lamellae remaining from resorptions of older secondary osteons.

No growth marks were observed in both specimens in longitudinal or transverse sections, with optic microscopic, but thick and rather loose bundles of Sharpey fibers, crossing each other at various acute angles, were seen in transversal sections (Figure. 4).

\section{INTERNAL MICROSTRUCTURE: MICRO-CT}

The main advantage of studying osteoderms under micro-CT, besides the possibility of viewing the whole three-dimensional (3D) architecture, is the observation of distribution, shape, size, and position of the cavities, as well as their interconnectivity, density, and anisotropy.

According to Cooper et al. (2003), Krmpotic et al. (2015), and Ciancio et al. (2017), the internal cavities within the osteoderms comprise: Havers and Volkmann channels (canal network - not observed by Ciancio et al. [2017]) due to the low resolution during image acquisition; bone marrow cavities with no external connection, filled with yellow and red bone marrows; piliferous follicle cavities opening at the external surface (saccular or spherical glandular cavities sensu Ciancio et al. [2017]) and channels for hypodermis ingression 

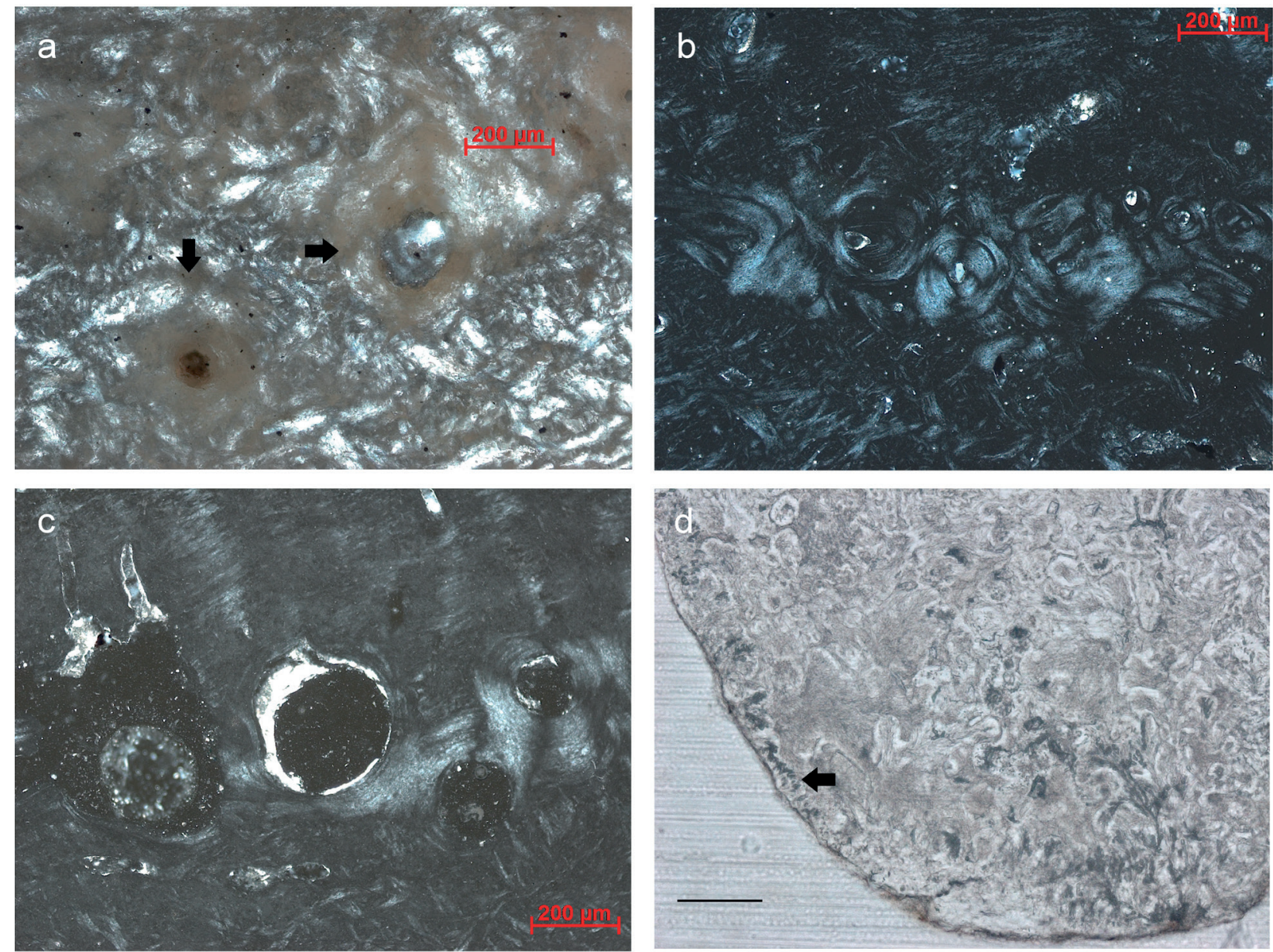

Figure 4 - Details of the vascularization of Riostegotherium yanei: a) the central portion of the specimen LMH 05 showing the sole primary osteon of the deep cortex (vertical arrow) and one of the secondary osteons of the core at the mid region of the tongue (horizontal arrow) (UFRJ-DG 1051M); b) and c) the secondary osteons and resorption areas of the core of the specimen LMH 06 at the tongue (UFRJ-DG 1050M and UFRJ-DG 1049M respectively); d) transversal section of the posterolateral portion of the specimen LMH 05 (UFRJ-DG 1051M) showing Sharpey fibers at the osteoderm margin. Scale bar $=50 \mu \mathrm{m}$.

from the internal surface. Ciancio et al. (2017) also recognized the presence of marginal piliferous follicle cavities in all analyzed species, but they seem not to be present in the scanned osteoderms of Riostegotherium yanei, except for a possible one in LMH 06.

The combining micro-CT analysis and histological sections, to study the internal anatomy of buckler osteoderms of the extant armadillos Chaetophractus villosus (Desmarest, 1804) and Dasypus hybridus (Desmarest, 1804) (Krmpotic et al. 2015, Ciancio et al. 2017), provide the data for the association proposed here between the internal cavities and some of the aforementioned internal structures. However, Hill (2006) argued that osteoderms of modern armadillos are physically associated with a variety of soft tissues, and in some cases, two or more different tissue types may cause similar osteological features. Thus, soft-tissue inferences for fossil osteoderms can be equivocal.

Two different patterns of distribution and cavity sizes were revealed in reconstructed osteoderms from movable bands (Figure 5). In Pattern 1, the cavities are much larger and more concentrated at the base, while in Pattern 2 the cavities are smaller and dispersed throughout the osteoderm. The video 

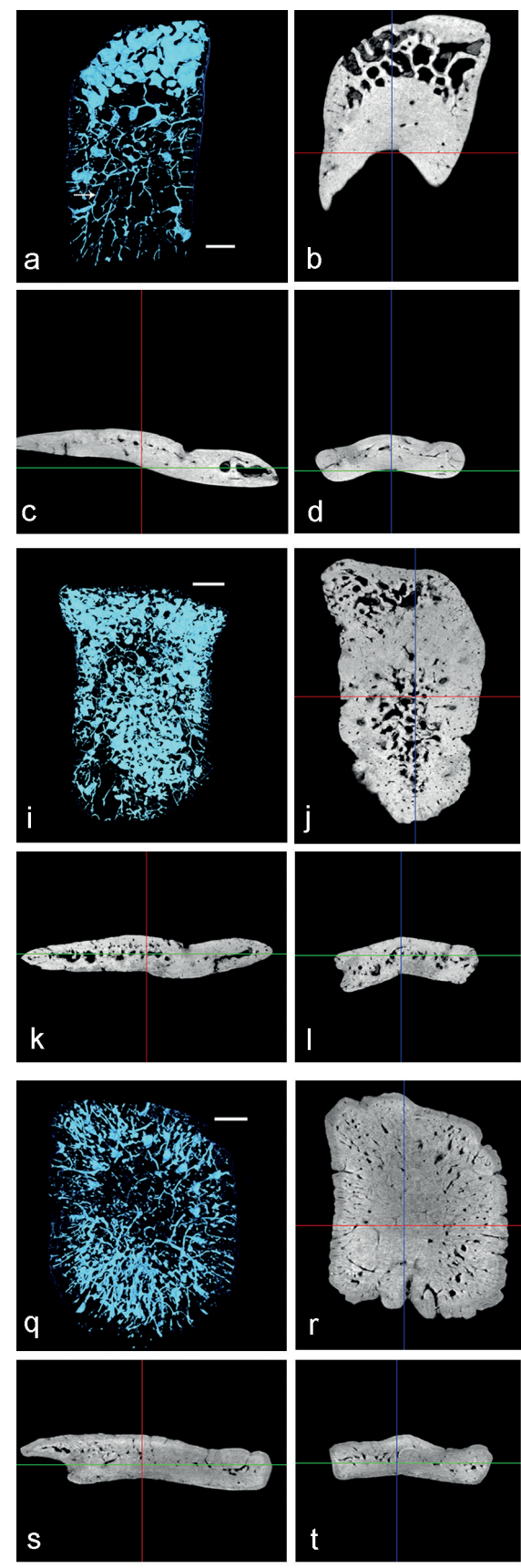
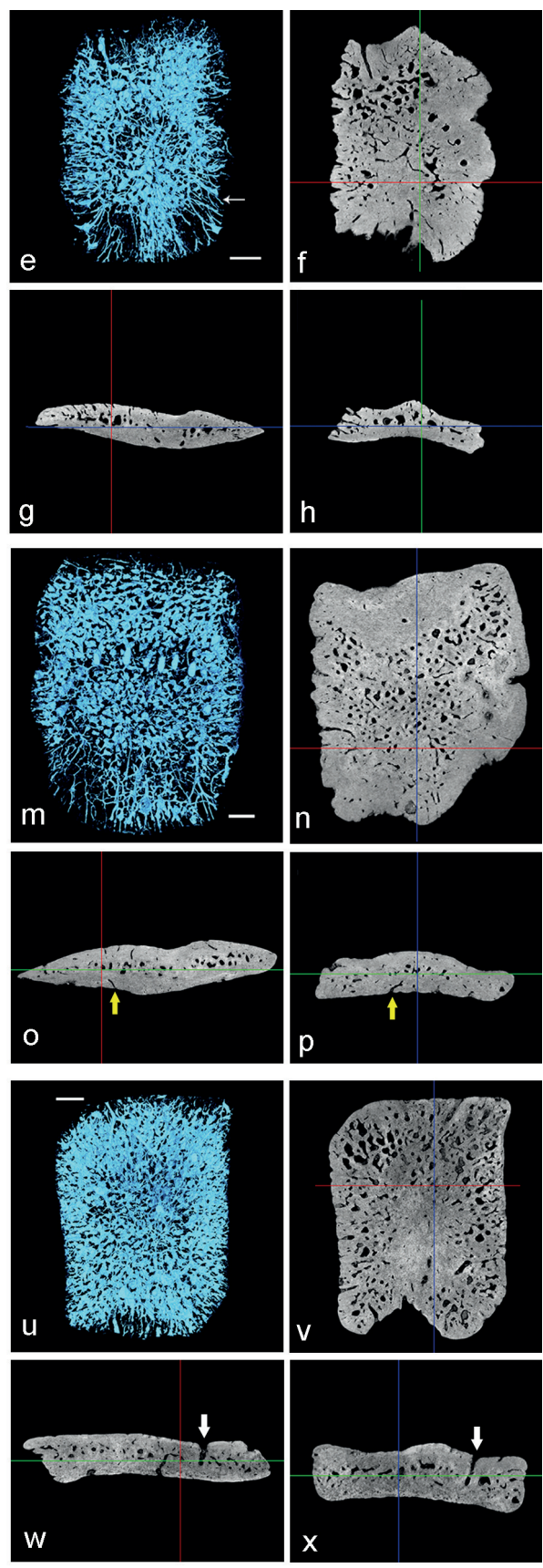

Figure 5 - Three-dimensional reconstruction of the porosity and internal view of osteoderms of Riosthegotherium yanei, showing the differences between Pattern 1 (a-d, q-t) and Pattern 2 (e-p, u-x). a) UFRJ-DG 317M, exhibiting large and irregular cavities anteriorly; b) LMH 06; c) MCN-PV 1777; d) MCN-PV 1779; e) MCT 3932M; f) MCN-PV 1775. Scale bar = $1 \mathrm{~mm}$. a-p, osteoderms from movable bands; q-x, buckler osteoderms. a, e, i, m, q, u, $3 \mathrm{D}$ reconstruction; $\mathbf{b}, \mathbf{f}, \mathbf{j}, \mathbf{n}, \mathbf{r}, \mathbf{v}$, dorsoventral view, anterior to the top; $\mathbf{c}, \mathbf{g}, \mathbf{k}, \mathbf{o}, \mathbf{s}, \mathbf{w}$, longitudinal view, anterior to the right; $\mathbf{d}, \mathbf{h}, \mathbf{l}, \mathbf{p}, \mathbf{t}, \mathbf{x}$, transversal view, dorsal to the top. White thin arrows indicate possible Havers and Volkmann channels. White thick arrows indicate the glandular cavity internal to piliferous foramina. Yellow thick arrows indicate hypoderm ingression. Colored lines are software axes exported with the images. Threedimensional reconstructions were made with CTVox and slices with Dataviewer. 
of each osteoderm (see supplementary material, videos 1-8) provides a definite difference between both patterns.

Pattern 1 is only observed in the specimen UFRJ-DG 317M (Figure 5a-c), in which the base is composed of large, irregular shaped cavities (porous medullary cavities sensu Hill 2006, bone marrow cavities sensu Ciancio et al. 2017), anastomosed, and extended over the entire area of the base. The cavities are larger transversally than dorsoventrally, and slightly displaced to the superficial surface of the osteoderm. In the extant Dasypus, these cavities are filled with both yellow and red marrow (Hill 2006), or yellow marrow only, since seasonal variation can suppress the development of red marrow (Krmpotic et al. 2015).

The frequency, size, and concentration of the cavities change dramatically posterior to the contact between base and tongue. At the tongue, the osteoderm is formed largely by compact bone, crossed by small and thin elongated "tubules" with multiple directions, although most have an anteroposterior orientation, and several are directed to the lateral margins.

Comparing to the data obtained in the histological sections, some of these tubules may correspond to Havers and Volkmann channels, others to smaller resorption areas, and some to neurovascular channels that are connected to the orifices at the external and internal surfaces of the osteoderm. The tubules decrease in thickness and frequency towards the posterior margin, where they are sparser and more isolated.

The glandular cavity internally to the large piliferous foramina of the superficial surface (external surface foramina sensu Ciancio et al. 2017) extend internally up to the mid region of the osteoderm (Figure 5w, x), except the most posterior foramen, which almost reaches the internal surface. Most are conical but with a blunt end, while others are cylindrical. The micro-CT resolution is not adequate to assert that the piliferous foramina are associated with hair follicles and/or glands, but in extant Dasypus surface piliferous follicles are always associated with sweat glands (Hill 2006, Krmpotic et al. 2015).

Riostegotherium yanei presents several small foramina at the deep surface, in contrast to Dasypus hybridus that bears a unique but large neurovascular ingression from the hypodermis (Krmpotic et al. 2015). The canals of $R$. yanei are much thinner than in the extant species; most anterior ones are interconnected with each other and with one of the external piliferous foramina; some reach the cavities of the central region and others seem only to penetrate, for some extent, the osteoderm (Figure $5 \mathrm{~m}-\mathrm{p}$, $\mathrm{u}-\mathrm{w}$; but better observed in the videos of the specimens provided as supplementary material).

The second organization of the cavities (Pattern 2) is observed in the remaining scanned osteoderms from movable bands (Figure 5e-p). As in UFRJ-DG $317 \mathrm{M}$, the base is filled with cavities, but unlike this specimen, the cavities are much smaller, more numerous, and more interconnected to each other by a tangling net of thin tubules. In LMH 06 (Figure 5e-h), they are more displaced posteriorly, leaving an area of compact bone along the anterior border, but in MCN-PV 1777 (Figure 5i-1) and 1779 (Figure 5m-p), the small cavities fill the base completely.

At the tongue, the cavities have about the same volume as those at the base and are more concentrated in the central region of the osteoderm, underneath the central keel in LMH 06 (Figure 5eh), although less in MCN-PV 1777 (Figure 5i-1). In MCN-PV 1779 (Figure 5m-p), they are equally distributed at the anterior half of the tongue, while compact bone prevails at the posterior half. In LMH 06 , the cavities almost disappear beside the central keel near the distal border. Following Ciancio et al. (2017), these cavities are regarded as small bone marrow cavities.

The cavities are closer to the superficial surface at the anterior half of the tongue, as already 
observed in the histological thin section (Figure 1b). Unlikely UFRJ-DG $317 \mathrm{M}$, no preferential direction of the cavities is present. The cavity underneath the piliferous external foramina is similar to UFRJ-DG 317M.

Both lateral borders are much deeper and rugose than in UFRJ-DG $317 \mathrm{M}$ (Figure 1), and bear a larger number of small foramina, whose canals extend internally, transversely to the main axis of the osteoderm.

Several small and some larger perforations for hypoderm ingression, mainly at the tongue, are present at the deep surface of LMH 06. The high density of cavities hampers tracking the path followed by the canals, except for the one near the anterior border, which extends almost to the contact of base and tongue and is probably connected to one of the external piliferous foramina.

The internal morphology of the two buckler osteoderms that were micro-CT scanned is quite distinct. The internal cavities (glandular and bone marrow cavities sensu Ciancio et al. 2017) of MCT 3932M (Figure 5q-t) are slender, resembling the pattern observed in UFRJ-DG 317M (Figure 5a-d). They are organized somewhat radially, leaving the central region of the osteoderm almost devoid of cavities and formed largely by compact bone. Due to the reduced number of cavities, MCT 3932M is the sole osteoderm in which the connection of several hypoderm ingressions with the internal cavities is visible (Figure 5q-t). The condition observed in MCN-PV 1775 (Figure 5u-x) matches the second pattern, in which a larger number of small and interconnected cavities fill the whole osteoderm. A much less distinct radial organization of the cavities seems to be present, but unlike MCT 3932M, the central region of the osteoderm is filled with cavities.

QUANTITATIVE 3D ANALYSIS OF THE CANAL NETWORK

As in long bone cortex, the osteoderms of fossil and extant Dasypodidae is perforated by an interconnected network of canals and cavities that facilitate the distribution of neurovascular and glandular structures throughout the cortical bone. Some of the parameters proposed to assess the canal network are employed here (Table I) to evaluate and quantify the differences in the two patterns observed among the analyzed osteoderms of Riostegotherium yanei. Although the data provided is not statistically significant due to the low number of variables and specimens, it represents an approach to investigate and compare the internal pattern of cavities among the oldest cingulate and its close living relatives.

The parameters of osteoderms from movable bands have no correlation between size (volume) and porosity. For instance, the total volume of MCN-PV 1777 is about one third of the volume of MCN-PV 1779, but it is almost two times more porous (Ca.V/TV) than MCN-PV 1777.

The percentage of porosity $(\mathrm{Ca} . \mathrm{V} / \mathrm{TV})$ in the four movable specimens scanned for $R$. yanei have similar values. However, when the size of the specimens (TV) is considered, MCN-PV 1779 becomes the densest specimen, as it has less cavities than the other three specimens, whereas MCN-PV 1777 is the most porous. Although the cavities of MCN-PV 1779 are most scattered in the anterior two thirds of the osteoderm (Figure 5m-p), they are smaller than in LMH 06 (Figure 5e-h), the second largest specimen and proportionally the most porous. The relative high porosity of the osteoderm UFRJ-DG $317 \mathrm{M}$ is due to the very large glandular cavities at the base, as most of the tongue of the specimen is denser (Figure 5a-d). This condition is clearly noted when the porosity is analyzed in a selected region of the base (VOI (Ca.V/TV)), in which UFRJ-DG $317 \mathrm{M}$ becomes up to $25 \%$ more porous than the second most porous osteoderm (LMH 06).

As already observed in the $3 \mathrm{D}$ reconstructions of buckler osteoderms (Figure 5q-x), MCN-PV 1775 is noticeably more porous than MCT 3932M, 
TABLE I

Parameters for quantitative assessment of cortical canal network of Riostegotherium yanei and Dasypus novemcinctus. Specimens LMH 98.1, 98.4 and 98.5 belong to a subfossil specimen of $D$. novemcinctus from Gruta do Urso, Tocantins state, Brazil. $\mathrm{B}=$ buckler; $\mathrm{BS} / \mathrm{BV}=$ solid surface to volume ratio measured in $3 \mathrm{D}$ within the VOI; $\mathrm{BV}=$ total volume of binarized objects within the VOI; Ca.ConnD = connectivity density; Ca.V/TV = canal volume to tissue volume ratio (porosity); $\mathrm{DA}=$ degree of anisotropy; $\mathrm{M}=$ movable; $\mathrm{VOI}=$ volume of interest (500 slices or $\left.3.63 \mathrm{~mm}^{3}\right)$; TV = Tissue volume.

\begin{tabular}{cccccccc}
\hline SAMPLE & TAXON & $\begin{array}{c}\text { TV } \\
\left(\mathrm{mm}^{3}\right)\end{array}$ & $\begin{array}{c}\text { Ca.V/TV } \\
(\%)\end{array}$ & $\begin{array}{c}\text { BS/BV } \\
\left(\mathrm{mm}^{-1}\right)\end{array}$ & DA & $\begin{array}{c}\text { Ca.ConnD } \\
\left(\mathrm{mm}^{-3}=\mu \mathrm{m}^{-1}\right)\end{array}$ & $\begin{array}{c}\text { VOI (Ca.V/ } \\
\mathbf{T V})(\%)\end{array}$ \\
\hline $\begin{array}{c}\text { UFRJ-DG 317M } \\
\text { (M) }\end{array}$ & R. yanei & 61.7 & 5.62 & 53.6 & 0.58 & 622 & 35.57 \\
LMH 06 (M) & R. yanei & 116 & 7.25 & 43.6 & 0.37 & 841 & 27.16 \\
MCN-PV 1777 (M) & R. yanei & 57.1 & 8.28 & 58.2 & 0.30 & 986 & 22.1 \\
MCN-PV 1779 (M) & R. yanei & 157 & 4.25 & 78.5 & 0.37 & 849 & 15.5 \\
MCT 3932M (B) & R. yanei & 138 & 2.37 & 82.3 & 0,33 & 679 & 7.55 \\
MCN-PV 1775 (B) & R. yanei & 143 & 8.22 & 66.8 & 0.32 & 809 & 16.11 \\
LMH 83.2 (M) & D. novemcinctus & 112 & 4.54 & 46.9 & 0.51 & 379 & 15.22 \\
LMH 83.5 (M) & D. novemcinctus & 208.09 & 25.53 & 16,05 & 0.59 & 736 & 63.5 \\
LMH 83.6 (M) & D. novemcinctus & 49.98 & 4.89 & 98.2 & 0.59 & 736 & 10.52 \\
LMH 83.1 (B) & D. novemcinctus & 81.8 & 4.52 & 62.2 & 0.39 & 560 & 24.4 \\
LMH 83.7 (B) & D. novemcinctus & 68.18 & 5.5 & 66.9 & 0.60 & 591 & 8.27 \\
LMH 98.1 (B) & D. novemcinctus & 63.11 & 4.38 & 173,43 & 0.49 & 2579 & 7.18 \\
LMH 98.4 (B) & D. novemcinctus & 63.71 & 2.73 & 105,75 & 0.45 & 797 & 11.29 \\
LMH 98.5 (B) & D. novemcinctus & 51.4 & 5.75 & 81,53 & 0.36 & 818 & 15.18 \\
\hline
\end{tabular}

especially when considering that both have almost the same tissue volume. The difference, although still noteworthy, decreases when only the VOI is considered.

In previous analyses (Odgaard 1997, Borah et al. 2001, Cooper et al. 2003), the degree of anisotropy (DA) was employed to measure the preferred orientation of the interconnections of the trabeculae or the porous canals. In these cases, branches transversely oriented to a predominantly longitudinally oriented network, acted to decrease the degree of anisotropy (Cooper et al. 2003). Comparison of the images of reconstructed porosity of each $R$. yanei specimen with their anisotropy values indicates that the most isotropic specimens are those in which the porosity is more equally spread all over the osteoderms. The specimens that alternate areas of intense porosity with denser areas, like UFRJ-DG $317 \mathrm{M}$, are more anisotropic.

As expected, the connectivity density (Ca. ConnD ) of UFRJ-DG 317M is also lower than other osteoderms from movable bands, as the cavities are larger and less abundant. The lower value of MCT 3932M may be related with the smaller number of cavities and consequent interconnections.

\section{DISCUSSION}

Although only isolated osteoderms of the carapace of Riostegotherium yanei have been found so far (Scillato-Yané 1976, Oliveira and Bergqvist 1998, Bergqvist et al. 2004), it is reasonable to believe that, as in other early cingulates, the bucklers were built of loosely joined elements and separated by an unknown number of movable bands, possibly 
more numerous than in extant cingulates (as seen in Stegotherium Ameghino, 1887, from the Miocene of Argentina; Scott 1903). The large proportion of osteoderms from movable bands recovered for $R$. yanei $(73 \%)$ agrees with this assumption. Osteoderms like MCN-PV 1777 (Figure 1) suggest a smooth transition between buckler and movable osteoderms, as is observed in Stegotherium tauberi González and Scillato-Yané 2008. Additionally, the paucity of osteoderms recovered at the Itaboraí basin argues for a carapace composed of fewer osteoderms than in later cingulates (Cifelli 1983, Bergqvist et al. 2004), although the scarcity of individuals in the original community and taphonomic bias cannot be discarded.

Wolf (2007) considered cingulate osteoderms as highly derived with respect to the small, compact, and isolated ossicles found in mylodontid sloths; however, the recent work of McDonald (2018) proposed that sloths and cingulates developed osteoderms independently. Several morphological and histological traits characterize the Neogene lineages, including the generally diploë-like structure, also present in the osteoderms of other vertebrates (e.g. Scheyer and Sander 2004).

Although $R$. yanei evidences the presence of osteoderms in the oldest known Xenarthra (Scillato-Yané 1976, Oliveira and Bergqvist 1998, Bergqvist et al. 2004), it is still unclear whether osteoderms were present in the common ancestor of Xenarthra and have been lost in Vermilingua and sloths (Wolf 2007), or if they were acquired independently in Cingulata and Pilosa as proposed by McDonald (2018).

The typical diploë-like structure of derived cingulates (Wolf 2007) is not obviously observed in the osteoderms of $R$. yanei because, as stated by Ciancio et al. (2017), the osteoderm of primitive Dasypodidae are mainly composed of compact bone. However, a three-layered structure with a central region, composed of secondarily remodeled osteons and areas of resorptions, is present in this oldest form.

Riostegotherium yanei is inferred to be the most basal Dasypodinae (Ciancio et al. 2017), belonging to a lineage (Astegotheriini) that diverged early within this group (which also includes the extant Dasypus). The external morphology of its osteoderms resembles both the primitive Stegosimpsonia Vizcaíno, 1994 and the derived Dasypus. However, in the internal morphology, although bearing some differences, $R$. yanei is closer to Dasypus than to other astegotheriines due to the presence of an intermediate layer full of cavities and to the absence saccular glandular cavities beneath external surface foramina.

The comparison of histological thin sections of osteoderms from movable bands of Riostegotherium yanei, Dasypus novemcinctus, and Dasypus bellus Simpson, 1929 (from Hill 2006, Wolf 2012, Krmpotic et al. 2015) suggests that the base of $R$. yanei is more compact than in both Dasypus species, but when the channel network is three-dimensionally quantified (Table I), this is not always true for the Dasypus specimens analyzed here. At the tongue, the cavities are larger in R. yanei, although fewer in number. Another distinction from Dasypus is noted in the central layer, where an area with numerous secondary osteons, as well as cavities, is present at the anterior third of the tongue in R. yanei (Figure 2). According to Wolf (2007) and Wolf et al. (2012), D. novencimctus and $D$. bellus are mainly formed by primary osteons and only few, if any, are secondarily remodeled.

The orientation of the fiber bundles at deep and superficial layers of $R$. yanei is also distinct from both Dasypus species previously studied (Hill 2006, Wolf et al. 2012). In R. yanei, the fibers are parallel to each other at the external cortex but unordered at the internal cortex, while the opposite happens in Dasypus novencinctus (but not in Dasypus bellus; Hill 2006, Wolf et al. 2012). 
Ciancio et al. (2017) did not provide any detailed histological description of the Argentinian Astegotheriini but only pictures of three different sections, which reveal a whole compact osteoderm, with no remodeling bone at the central region. The development of the central layer is distinct in the two buckler osteoderms of $R$. yanei (Figure 5), but it is definitely present in both. Moreover, the cavities internal to the piliferous external aperture of the Argentine Astegotheriini are much larger, deeper, and saccular.

Considering the previously mentioned affinity between Dasypodinae and $R$. yanei, several isolated osteoderms of Dasypus novemcinctus were scanned and reconstructed (see supplementary material videos 7,8). As already observed in histological sections (Hill 2006), the entire base of $D$. novemcinctus bears large cavities filled with bone marrow (Figure 6). The same pattern of large glandular cavities at the base was observed in histological sections of Dasypus hybridus (Krmpotic et al. 2015), but unfortunately, no previous author presented a $3 \mathrm{D}$ reconstruction of osteoderms from movable bands of this species (Krmpotic et al. 2015, Ciancio et al. 2017). The $3 \mathrm{D}$ reconstruction of $D$. novemcinctus confirmed the more compact condition of the osteoderm at the tongue (also noticed from histological sections). No bone marrow cavities seem to be present, but the saccular cavities underneath the external surface foramina for piliferous follicles are interconnected with each other by a longitudinal thick and central channel, with thin (in longer osteoderms) or thick (in shorter osteoderms) bifurcations. The marginal piliferous follicle cavities (two to four within the species observed) become larger at its middle portion and taper anteriorly, where they connect with the large canal cited above.

The buckler osteoderms of $D$. novemcinctus display a radial orientation of the cavities (also present in Dasypus hybridus; Krmpotic et al. 2015). The glandular cavities beneath the external surface foramina are interconnected to each other and with the marginal piliferous cavities by thick canals forming a circular outline, (Figure 6), linked to a unique neurovascular ingression from the hypodermis (Hill 2006, Krmpotic et al. 2015).

As previously mentioned, two distinct patterns of internal porosity are present within the Itaborai specimens studied here. The movable osteoderm UFRJ-DG 317M (Pattern 1) resembles Dasypus (Figure 6) with the presence of large cavities at the base. The thin and branched channels observed in both taxa (but not by Krmpotic et al. 2015 and Ciancio et al. 2017) were associated here with Havers and Volkmann channels (following Stout et al. 1999). The haversian system is the major microstructural feature of compact bone in most mammals and other vertebrates, and the death of the animals leaves these cavities unfilled. Particelli et al. (2011) analyzed several cortices of human femora and tibiae and concluded that comparative results between micro-CT analysis and histological sections showed no significant differences in cortical porosity, Haversian canal diameter, and Haversian canal separation. Those thin and branched cavities are only observed in more compact areas of the osteoderms of $R$. yanei and D. novemcinctus, because the glandular and bone marrow cavities obliterate them where they are extensive.

Different from Dasypus, both patterns of movable and buckler osteoderms of Riostegotherium bear multiple small foramina at the internal surface (Figure 5) and not a large foramen for hypoderm ingression.

Concerning buckler osteoderms, the specimen MCT 3932M (Pattern 1) resembles Dasypus in the presence of an incipient radial orientation of the canal network, although the cavities below the external aperture are not linked by a channel.

The 3D reconstruction of a buckler osteoderm of Dasypus hibridus provided by Krmpotic et al. (2015) and Ciancio et al. (2017) is distinct from all buckler osteoderms of Dasypus novencinctus 


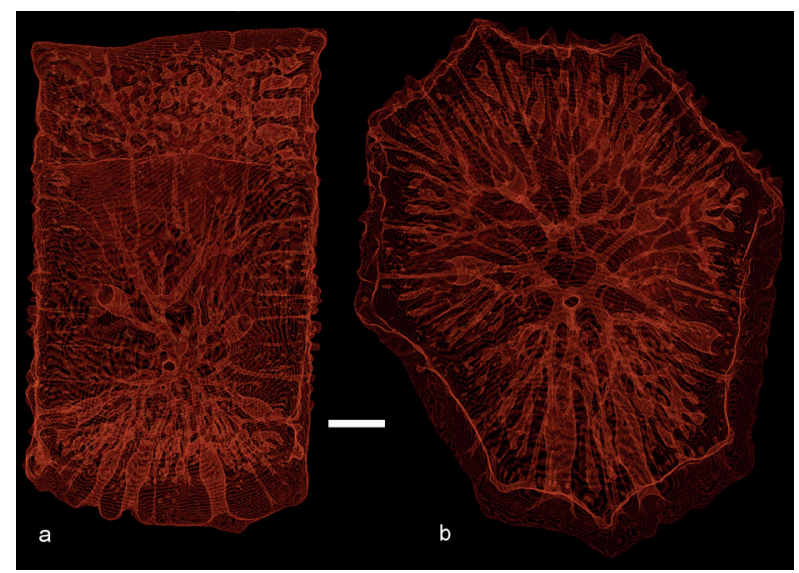

Figure 6 - Three-dimensional reconstruction of Dasypus novemcinctus osteoderms; a) LMH 83.2 (movable, anterior to the top); b) LMH 83.1 (buckler). Scale bar $=1 \mathrm{~mm}$.

analyzed here, as none present such big yellow (or red) bone marrow cavities. This difference, however, must be taken with caution as the 3D resolution of the specimens studied here is about six times higher than in their publication. A higher resolution provides more detailed internal structure, the porous space became more complex, while in lower resolution, the small bone structures are obliterated and clustered together.

Pattern 2 of both movable and buckler osteoderm is distinct from both Dasypus species and even more distinct from all astegotheriins. The quantity, size, and distribution of the cavities (bone marrow cavities sensu Ciancio et al. 2017) resemble that of Meteutatus lagenaformis Ameghino, 1897, but this similarity can be an artefact of the different resolution of each acquisition.

Owen $(1842,1861)$ noticed the absence of medullary cavity in the humerus, femur, and tibia of Glossotherium Owen, 1839 and Megatherium Cuvier, 1796, as well as in extant sloths. Extant armadillos also lack medullary canal, and Weiss and Wislocki (1956) suggested that hematopoietic activity of armadillos occurs inside the large cavities of the cranial portion (base) of the osteoderms from movable bands. Krmpotic et al. (2015) also found blood cell-producing tissue (red bone marrow) in osteoderms of the cephalic shield and pelvic buckler of Chaetophractus villosus and Zaedyus pichiy (Desmarest, 1804), respectively. Bergqvist et al. (2004) assigned some of the isolated long bones (humeri and ulnae) recovered in the Itaboraí Basin to Xenarthra. None of them exhibit a medullary canal, suggesting that the oldest known cingulate probably already had hematopoietic activity in the carapace. However, in the second pattern of cavity shape and distribution described above, the cavities are of equal size and are disperse along the entire osteoderm. We suggest that some of these (not only the ones present in the base) were responsible for the hematopoiesis in Riostegotherium yanei.

In addition to the osteoderms of $R$. yane $i$ showing two patterns of internal cavities distribution, as mentioned before, two isolated humeri and astragali with different morphology and size were associated to the Itaboraian cingulates by Cifelli (1983) and Bergqvist et al. (2004). The radial organization of the cavities, in the buckler osteoderm MCT 3932M, the intense porosity at the base, and the denser condition at the tongue, in the specimen UFRJ-DG 317M, are features also present in Dasypus (Figures 5, 6; Ciancio et al. 2017). The morphology of the larger humerus and astragalus are closer to Dasypodidae species than the smaller ones. Although only few osteoderms of $R$. yanei have been recovered and the variation of the internal morphology within the carapace is unknown, we cannot rule out the possibility that the postcranial bones with Dasypodidae morphology (Bergqvist et al. 2004), and the osteoderms MCT $3932 \mathrm{M}$ and UFRJ-DG $317 \mathrm{M}$ belong to the same species, whereas the remaining osteoderms, together with the smaller astragalus and humerus, belong to another species.

\section{CONCLUSIONS}

The osteoderms of the oldest Xenarthra Riostegotherium yanei lacks the diploë-like 
structure typical of glyptodonts but present a three-layered structure composed of two layers of non-Haversian compact bone enclosing a central layer of primary and secondary osteons. This internal organization is entirely distinct from other Astegotheriini of comparable age, who present a fully compact osteoderm, but is similar to the extant Dasypus. Although a larger number of specimens are needed for a more sustained conclusion, we suggest that $R$. yanei is closer to the lineage leading to Dasypus than to Astegotheriini.

The 3D reconstructions of the osteoderms recovered from the Itaboraí basin reveal the presence of two patterns of internal organization of the cavities among them, though externally they all bear the same morphology. Pattern 1 of movable osteoderm (UFRJ-DG 317M) is composed of large remodeled areas at the base and a more compact bone at the tongue, while in Pattern 2 (remaining specimens) the cavities are much smaller, more numerous and more interconnected to each other by a tangling net of thin tubules. This pattern is also observed in one buckler osteoderm, but in the other buckler osteoderm (MCT 3932M), the cavities are organized somewhat radially, leaving the central region of the osteoderm almost devoid of cavities and formed largely by compact bone (Pattern 1). A radial organization of the internal cavities is the pattern of Dasypus novencinctus and D. hybridus. The closer resemblance of Pattern 1 with Dasypus can be tentatively used to associate UFRJ-DG 317M and MCT 3932M to the dasypodoid postcranium recovered from the Itaboraí basin, even if the variability of the internal structure of osteoderms of an individual is unknown.

The combining of histology and microtomography for studying cingulate osteoderms offers both details and spatial distribution of the internal structure; however, the resolution of acquisition may restrict the structures observed. For observation of smaller structures like
Havers and Volkman channels, a resolution of 15 $\mu \mathrm{m}$ or less is suggested.

\section{ACKNOWLEDGMENTS}

We thank R. R. Machado (MCT) and A. M. Ribeiro (FZB) for allowing the study of specimens under their care; the Laboratório de Geologia Sedimentar (LAGESED/UFRJ) for access to the petrographic microscope and the Laboratório de Petrofísica of Departamento de Geologia/UFRJ for some of the Micro-Computed acquisitions. We also thank A. G. Rodrigues (LAGESED), for the support with petrographic microscope; M. Farina (Laboratório de Biomineralização/UFRJ), for profitable discussions; and to the students L. Beltrame and G. Victer for their contributions to the first version of the manuscript. We are also grateful to two anonymous reviewers for their helpful comments and corrections. Support for this project was partially provided by Conselho Nacional de Desenvolvimento Científico e Tecnológico (CNPq, 304129/2016-0).

\section{AUTHOR CONTRIBUTIONS}

L.P.B. come up with the idea and was responsible for elaborating the manuscript; P.V.L.G.C.P. helped with the description and photography of the histological thin sections; M.C.C. found specimens of Riostegotherium yanei in MCT unnumbered collection and helped with the discussion; A.S.M. and R.T.L. performed the methodology and the experiments of computerized microtomography (micro-CT) and helped to interpret the micro-CT data analysis; L.B.M. performed image and video processing and helped with bibliography. All authors contributed with the main text and revising the final version of the manuscript.

\section{REFERENCES}

AGUIAR JM AND FONSECA GD. 2008. Conservation status of the Xenarthra. In: Vizcaíno SF and Loughry WJ (Eds), 
The Biology of The Xenarthra: University Press of Florida, Gainesville, p. 215-231.

AMEGHINO F. 1887. Enumeración sistemática de las especies de mamíferos fóssiles coleccionados por C. Ameghino em los terrenos eocenos de la Patagonia austral. In: Ameghino Obras 5: 447-668.

AMEGHINO F. 1897. Mammifères crétacés de l'Argentine. Deuxième contribution à la coinassance de la faune mammalogique des couches à Pyrotherium. In: Ameghino Obras 12: 301-461.

AMEGHINO F. 1902. Notices préliminaires sur des mammifères nouveaux des terrains Crétacé de Patagonie. In: Ameghino Obras 13: 738-829

BERGQVIST LP, ABRANTES EAL AND AVILLA LS. 2004. The Xenarthra (Mammalia) of São José de Itaboraí Basin (upper Paleocene, Itaboraian), Rio de Janeiro, Brazil. Geodiversitas 26: 323-337.

BERGQVIST LP AND OLIVEIRA EV. 1998. Comments on the xenarthran astragali from the Itaboraí Basin (middle Paleocene) of Rio de Janeiro, Brazil. Acta Geol Lilloana 18: 153-154.

BOND M, CARLINI AA, GOIN FJ, LEGARRETA L, ORTIZJAUREGUIZAR E, PASCUAL R AND ULIANA MA. 1995. Episodes in South American land mammal evolution and sedimentation: testing their apparent concurrence in a Paleocene succession from central Patagonia. Actas VI Congreso Argentino de Paleontología y Bioestratigrafía, Trelew, Argentina, p. 47-58.

BORAH B, GROSS GJ, DUFRESNE TE, SMITH TS, COCKMAN MD, CHMIELEWSKI PA, LUNDY MK, HARTKE JR AND SOD EW. 2001. Three-dimensional microimaging ( $\mathrm{MR} \mu \mathrm{I}$ and $\mu \mathrm{CT})$, finite element modeling, and rapid prototyping provide unique insights into bone architecture in osteoporosis. Anat Rec 265(2): 101-110.

CARLINI AA, CIANCIO MR, FLYNN JJ, SCILLATOYANÉ GJ AND WYSS AR. 2009. The phylogenetic and biostratigraphic significance of new armadillos (Mammalia, Xenarthra, Dasypodidae, Euphractinae) from the Tinguirirican (Early Oligocene) of Chile. J Syst Palaeontol 7: 489-503.

CHAVÉZ-APONTE O, ALFONZO-HERNÁNDEZ I, JOSÉ FINOL H, BARRIOS NCE, BOADA-SUCRE A AND CARRILO-BRICEÑO JD. 2008. Histología y ultraestructura de los osteodermos fósiles de Glyptodon clavipes y Holmesina sp. (Xenarthra:Cingulata). Interciencia 33: 616-619.

CIANCIO MR, KRMPOTIC CM, SCARANO AC AND EPELE MB. 2017. Internal morphology of osteoderms of extinct armadillos and its relationship with environmental conditions. J Mamm Evol: 1-13.

CIFELLI RL. 1983. Eutherian tarsals from the Late Paleocene of Brazil. Am Mus Novit 2761: 1-31.
COOPER DML, TURINSKY AL, SENSEN CW AND HALLGRIMSSON B. 2003. Quantitative 3D analysis of the canal network in cortical bone by micro-computed tomography. Anat Rec 274: 169-179.

COOPER D, TURINSKY A, SENSEN C AND HALLGRIMSSON B. 2007. Effect of voxel size on 3D micro-CT analysis of cortical bone porosity. Calcified Tissue Int 80: 211-219.

COPE ED. 1889. The Edentata of North America. Am Nat 23: 657-664.

CURREY JD. 2006. Bones Structure and Mechanics. Princeton University Press, Princeton, 436 p.

CUVIER G. 1796. Notice sur le squelette d'une très-grande espèce de quadrupède inconnue jusqu'à présent, trouvé au Paraguay, et déposé au Cabinet d'Histoire naturelle de Madrid. Magazin Encyc 52: 253-267.

DELSUC F, SUPERINA M, TILAK MK, DOUZERY EJ AND HASSANIN A. 2012. Molecular phylogenetics unveils the ancient evolutionary origins of the enigmatic fairy armadillos. Mol Phylogenet Evol 62: 673-680.

DESMAREST A. 1804. Tableau methodique des mammiferes. Nouveau dictionnaire d'histoire naturelle 24: 5-58.

ENGELMANN GF. 1985. The phylogeny of the Xenarthra, In: MONTGOMERY GG (Ed), The Evolution and Ecology of Armadillos, Sloths and Vermilinguas: Smithsonian Institution Press, Washington, DC, p. 51-64.

FELDKAMP LA, DAVIS LC AND KRESS JC. 1984. Practical cone-beam algorithm. J Opt Soc Am 1: 612-619.

FITZINGER LJ. 1871. Die natürliche Familie der Gürtelthiere (Dasypodes). Anz. Österreich. Akad. Wiss. Math.-Natur. K1 64: 329-390.

GAUDIN TJ AND WIBLE JR. 2006. The Phylogeny of Living and Extinct Armadillos (Mammalia, Xenarthra, Cingulata): A Craniodental Analysis, In: Carrano MT et al. (Eds), Amniote Paleobiology: Perspectives on the Evolution of Mammals, Birds, and Reptiles: University of Chicago Press, Chicago, IL, p. 153-198.

GELFO JN, GOIN FJ, WOODBURNE MA AND MUIZON C DE. 2009. Biochronological relationships of the earliest South American Paleogene mammalian faunas. Palaeontology 52: 251-269.

GIBB GC, CONDAMINE FL, KUCH M, ENK J, MORAESBARROS N, SUPERINA M, POINAR HN AND DELSUC F. 2015. Shotgun mitogenomics provides a reference phylogenetic framework and timescale for living xenarthrans. Mol Biol Evol 33: 621-642.

GONZÁLEZ LR AND SCILLATO-YANÉ GJ. 2008. Una nueva especie de Stegotherium Ameghino (Xenarthra, Dasypodidae, Stegotheriini) del Mioceno de la provincia de Santa Cruz (Argentina). Ameghiniana 45: 641-648.

GRAY JE. 1821. On the natural arrangement of vertebrose animals. London Medical Repository 15: 296-310. 
HILL RV. 2006. Comparative Anatomy and histology of xenarthran osteoderms. J Morphol 267: 1441-1460.

HOLMES WW AND SIMPSON GG. 1931. Pleistocene exploration and fossil edentates in Florida. B Am Mus Nat Hist 59: 383-418.

ILLIGER C. 1811. Prodromus systematis mammalium et avium additis terminis zoographicis utriudque classis. C. Salfeld, Berlin, $301 \mathrm{pp}$.

KRMPOTIC CM, CIANCIO MR, BARBEITO CG, MARIO RC AND CARLINI AA. 2009. Osteoderm morphology in recent and fossil euphractine xenarthrans. Acta Zool 90: 339-351.

KRMPOTIC CM, CIANCIO MR, CARLINI AA, CASTRO MC, SCARANO AC AND BARBEITO CG. 2015. Comparative histology and ontogenetic change in the carapace of armadillos (Mammalia: Dasypodidae). Zoomorphology 134: 601-616.

LINNAEUS CV. 1758. Systema Naturae per regna tria naturae. Secundum classes, ordines, genera, species, cum characteribus, differentiis, synonymis, locis 1-10, $823 \mathrm{p}$.

MCDONALD HG. 2018. An overview of the presence of osteoderms in sloths: implications for osteoderms as a plesiomorphic character of the Xenarthra. J Mamm Evol 25: 485-493.

MARSHALL LG. 1985. Geochronology and land-mammal biochronology of the transamerican faunal interchange. In: Stehli FG and Webb SD (Eds), The Great American Biotic Interchange, Plenum, New York, p. 49-85

MEREDITH RW ET AL. 2011. Impacts of the Cretaceous Terrestrial Revolution and KPg Extinction on mammal Diversification. Science 334: 521-524.

OLIVEIRA AI. 1956. Brazil. In: Jenks WF (Ed), Handbook of South American Geology, Geol Soc of Am 65: 1-62.

OLIVEIRA EV AND BERGQVIST LP. 1998. A new Paleocene armadillo (Mammalia, Dasipodoidea) from the Itaboraí Basin, Brazil. Asociación Paleontológica Argentina, Publicación Especial 5 Paleógeno de América Del Sur y de La Península Antártica, 35-40.

OLIVEIRA MFS, LIMA I, FERRUCIO PL, ABREU CJ, BORGHI L AND LOPES RT. 2011. Petrophysical analysis of limestone rocks by nuclear logging and 3D high-resolution X-ray computed microtomography. Nucl Instrum Meth A 652: 905-910.

ODGAARD A. 1997. Three-dimensional methods for quantification of cancellous bone architecture. Bone 20: 315-328.

OWEN R. 1839. The zoology of the voyage of the H. M. S. Beagle. Part I: Fossil Mammalia, p. 1-112.

OWEN R. 1842. Description of the skeleton of an extinct gigantic sloth, Mylodon robustus, Owen, with observations on the osteology, natural affinities, and probable habits of the megatherioid quadruped in general. London, R. and J. E. Taylor, $176 \mathrm{p}$.
OWEN R. 1861. Memoir on the Megatherium, or giant ground sloth of America (Megatherium americanum, Cuvier), London, Williams and Norgate, $84 \mathrm{p}$.

PARTICELLI F, MECOZZI L, BERAUDI A, MONTESI M, BARUFFALDI F AND VICECONTI M. 2011. A comparison between micro-CT and histology for the evaluation of cortical bone: effect of polymethylmethacrylate embedding on structural parameters. J Microsc-Oxford 245: 302-310.

PASCUAL R AND ORTIZ-JAUREGUIZAR E. 2007. The Gondwanan and South American Episodes: Two Major and Unrelated Moments in the History of the South American Mammals. J Mamm Evol 14: 75-137.

PAULA-COUTO C. 1949. Novas observações sobre paleontologia e geologia do depósito calcário de São José de Itaboraí. Notas Prelim Estud Serv Geol Mineral Brasil 49: 1-13.

PFEIFFER F, CROWDER C AND BROWN M. 2006. Secondary Osteon and Haversian Canal Dimensions as Behavioral Indicators. Am J Phys Anthropol 131: 460-468.

ROSE KD AND EMRY RJ. 1993. Relationship of Xenarthra, Pholidota, and Fossil "Edentates": themorphological evidence. In: Szalay FS, Novacek MJ and Mckenna MC (Eds), Mammal Phylogeny: Placentals: Springer-Verlag, New York, p. 81-102.

SCILLATO-YANÉ GJ. 1976. Sobre un Dasypodidae (Mammalia, Xenarthra) de edad Riochiquense (Paleoceno superior) de Itaboraí (Brasil). An Acad Bras Cien 48: $527-$ 530.

SCOTT WB. 1903. Mammalia of the Santa Cruz beds. I. Edentata. In: Scott WB (Ed), Reports of the Princeton University Expeditions to Patagonia 1896-1899, Princeton University Press, Princeton, 364 p.

SCHEYER TM AND SANDER PM. 2004. Histology of ankylosaur osteoderms: Implications for systematics and function. J Vertebr Paleontol 24: 874-893.

SIMPSON GG. 1929. Pleistocene mammalian fauna of the Seminole Field, Pinellas County, Florida. B Am Mus Nat Hist 56: 561-599.

STOCK SR. 2008. Recent advance in X-ray microtomography applied to materials. Int Mater Rev 53: 129-181.

STOUT SD, BRUNSDEN BS, HILDEBOLT CF, COMMEAN PK, SMITH KE AND TAPPEN NC. 1999. Computerassisted 3D reconstruction of serial sections of cortical bone to determine the $3 \mathrm{D}$ structure of osteons. Calcified Tissue Int 65: 280-284.

VIZCAÍNO SF. 1994. Sistematica y anatomía de los Astegotheriini Ameghino, 1906 (Nuevo Rango) (Xenarthra, Dasypodidae, Dasypodinae). Ameghiniana 31(1): 3-13

VIZCAÍNO SF. 1995. Identificación específica de las “mulitas”, género Dasypus L. (Mammalia, Dasypodidae), 
del noroeste argentino: descripción de una nueva especie. Mastozool Neotrop 2: 5-13.

WETZEL RM. 1985a. Taxonomy and distribution of armadillos Dasypodidae. In: Montgomery GG (Ed), The Evolution and Ecology of Armadillos, Sloths and Vermilinguas: Smithsonian Institution Press, Washington, DC, p. 23-46.

WETZEL RM. 1985b. The identification and distribution of recent Xenarthra (=Edentata) In: Montgomery GG (Ed), The Evolution and Ecology of Armadillos, Sloths and Vermilinguas: Smithsonian Institution Press, Washington, DC. p. 5-21.

WEISS LP AND WISLOCKI GB. 1956. Seasonal variations in hematopoiesis in the dermal bones of the nine-banded armadillo. Anat Rec 126: 143-163.

WOLF D. 2007. Osteoderm Histology of Extinct and Recent Cingulata and Phyllophaga (Xenarthra, Mammalia): Implications for Biomechanical Adaptation and Systematics. Hallesches Jahrb Geowiss Beiheft 23: 145151.

WOLF D, KALTHOFF DC AND SANDER PM. 2012. Osteoderm histology of the Pampatheriidae (Cingulata, Xenarthra, Mammalia): implications for systematics, osteoderm growth, and biomechanical adaptation. J Morph 273: 388-404.

WOODBURNE MO. 2010. The Great American Biotic Interchange: dispersals, tectonics, climate, sea level and holding pens. J Mamm Evol 17: 245-264.

WOODBURNE MA, GOIN FJ, RAIGEMBORN MS, HEIZLER M, GELFO JN AND OLIVEIRA EV. 2014. Revised timing of the South American early Paleogene land mammal ages. J S Am Earth Sci 54: 109-119.

\section{SUPPLEMENTARY MATERIAL}

Table SI - Acquisition parameters.
Video 1 - Video of a movable osteoderm of Riostegotherium yanei (UFRJ-DG $317 \mathrm{M}$ ) showing internal structure by changing channel opacity. Made with CTVox over CT scan images.

Video 2 - Video of a movable osteoderm of Riostegotherium yanei (LMH 06) showing internal structure by changing channel opacity. Made with CTVox over CT scan images.

Video 3 - Video of a movable osteoderm of Riostegotherium yanei (MCN-PV 1779) showing internal structure by changing channel opacity. Made with CTVox over CT scan images.

Video 4 - Video of a movable osteoderm of Riostegotherium yanei (MCN-PV 1777) showing internal structure by changing channel opacity. Made with CTVox over CT scan images.

Video 5 - Video of a buckler osteoderm of Riostegotherium yanei (MCN-PV 1775) showing internal structure by changing channel opacity. Made with CTVox over CT scan images.

Video 6 - Video of a buckler osteoderm of Riostegotherium yanei (MCT 3932M) showing internal structure by changing channel opacity. Made with CTVox over CT scan images.

Video 7 - Video of a movable osteoderm of Dasypus novemcinctus (LMH 83.2) showing internal structure by changing channel opacity. Made with CTVox over CT scan images.

Video 8 - Video of a buckler osteoderm of Dasypus novemcinctus (LMH 83.1) showing internal structure by changing channel opacity. Made with CTVox over CT scan images. 